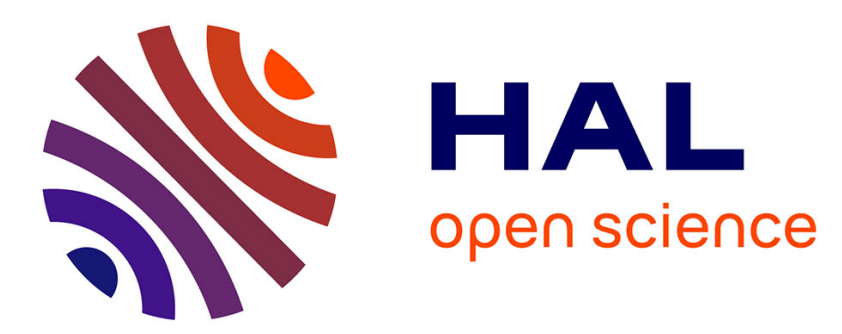

\title{
Selective Glucocorticoid Receptor Agonists (SEGRAs): Novel ligands with an improved therapeutic index
}

\author{
Heike Schäcke, Markus Berger, Hartmut Rehwinkel, Khusru Asadullah
}

\section{To cite this version:}

Heike Schäcke, Markus Berger, Hartmut Rehwinkel, Khusru Asadullah. Selective Glucocorticoid Receptor Agonists (SEGRAs): Novel ligands with an improved therapeutic index. Molecular and Cellular Endocrinology, 2007, 275 (1-2), pp.109. 10.1016/j.mce.2007.05.014 . hal-00531931

\section{HAL Id: hal-00531931 \\ https://hal.science/hal-00531931}

Submitted on 4 Nov 2010

HAL is a multi-disciplinary open access archive for the deposit and dissemination of scientific research documents, whether they are published or not. The documents may come from teaching and research institutions in France or abroad, or from public or private research centers.
L'archive ouverte pluridisciplinaire HAL, est destinée au dépôt et à la diffusion de documents scientifiques de niveau recherche, publiés ou non, émanant des établissements d'enseignement et de recherche français ou étrangers, des laboratoires publics ou privés. 


\section{Accepted Manuscript}

Title: Selective Glucocorticoid Receptor Agonists (SEGRAs):

Novel ligands with an improved therapeutic index

Authors: Heike Schäcke, Markus Berger, Hartmut Rehwinkel, Khusru Asadullah

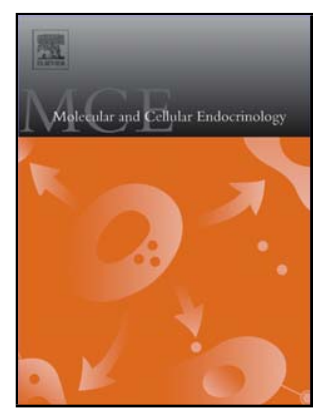

PII:

S0303-7207(07)00213-4

DOI: doi:10.1016/j.mce.2007.05.014

Reference: MCE 6665

To appear in: $\quad$ Molecular and Cellular Endocrinology

Received date: $\quad 2-4-2007$

Revised date: 22-5-2007

Accepted date: $\quad$ 23-5-2007

Please cite this article as: Schäcke, H., Berger, M., Rehwinkel, H., Asadullah, K., Selective Glucocorticoid Receptor Agonists (SEGRAs): Novel ligands with an improved therapeutic index, Molecular and Cellular Endocrinology (2007), doi:10.1016/j.mce.2007.05.014

This is a PDF file of an unedited manuscript that has been accepted for publication. As a service to our customers we are providing this early version of the manuscript. The manuscript will undergo copyediting, typesetting, and review of the resulting proof before it is published in its final form. Please note that during the production process errors may be discovered which could affect the content, and all legal disclaimers that apply to the journal pertain. 
Invited review for

Selective Glucocorticoid Receptor Agonists (SEGRAs): novel ligands with an improved therapeutic index.

Heike Schäcke*, Markus Berger ${ }^{\#}$, Hartmut Rehwinkel ${ }^{\#}$, and Khusru Asadullah* Bayer Schering Pharma AG, Global Drug Discovery, ${ }^{*}$ TRG Inflammation / Immunology, "Medicinal Chemistry, Berlin, Germany

Corresponding author:

Heike Schäcke, Ph.D.

Bayer Schering Pharma AG

TRG Inflammation \& Immuno logy

Müllerstr. 178

13342 Berlin

e-mail: heike.schaecke@schering.de

tel.: $\quad+49-30-4681-5971$

fax: $\quad+49-30-4689-5971$ 


\begin{abstract}
Glucocorticoids are belong the most successful therapies in the treatment of chronic inflammatory and autoimmune diseases. Their efficacy seems to be caused by the interference of the ligand-activated glucocorticoid receptor with many pro-inflammatory pathways via different mechanisms. The ubiquitous expression of the glucocorticoid receptor is a prerequisite for efficacy. Their main drawback, however, is due to their potential to induce adverse effects, in particular upon high dosage and prolonged usage. For the purpose reducing systemic side effects, topical glucocorticoids that act locally have been developed. Nevertheless, undesirable cutaneous effects such as skin atrophy persist from the use of topical glucocorticoids. Therefore a high medical need exists for drugs as effective as glucocorticoids but with a reduced side effect profile. Glucocorticoids function by binding to and activating the glucocorticoid receptor which positively or negatively regulates the expression of specific genes. Several experiments suggest that negative regulation of gene expression by the glucocorticoid receptor accounts for its anti-inflammatory action. This occurs through direct or indirect binding of the receptor to pro-inflammatory transcription factors that are already bound to their regulatory sites. The positive action of the receptor occurs through homodimer binding of the ligand receptor complex to discrete nucleotide sequences and this contributes to some of the adverse effects of the hormone. Glucocorticoid receptor ligands that promote the negative regulatory action of the receptor with reduced positive regulatory function should therefore show an improved therapeutic index. A complete separation of the positive from the negative regulatory activities of the receptor has so far not been possible because of the interdependent nature of the two regulatory processes. Nevertheless, recent understanding of the molecular mechanisms of the GR has triggered several drug discovery programs and these have led to the identification of dissociated GR-ligands. Such selective GR agonists (SEGRAs) are likely to enter clinical testing soon.
\end{abstract}




\section{Introduction}

Glucocorticoids (GCs) are among the most effective therapies in the treatment of acute and chronic inflammatory, as well as autoimmune diseases. They have been applied successfully in a clinical setting for more than half a century. The era of GCs began with the discovery that the adrenal hormone, cortisol, was able to reverse the symptoms and dysfunctions associated with Addison disease (Mason et al., 1936, Mason et al., 1936 A). After observing high efficacy in the treatment of rheumatoid arthritis (RA) when cortisol was administered pharmacologically (Hench et al., 1949, Hench et al., 1950), a tremendous development of systemic and topical GCs for use in several therapeutic fields was initiated. Early on, interest in more potent compounds was high and consequently such compounds were synthesized. With the application of highly potent GCs, especially over long times, however, undesired effects became more apparent. A number of these effects such as osteoporosis, diabetes, Cushing's syndrome, glaucoma and muscle atrophy are severe and sometimes irreversible (Schäcke et al., 2002, Miner et al., 2005). The incidence of side effects depends on the potency of the used GC, the administration route, the indication, and the individual treated. Some indications such as dermatologic diseases or asthma have also been found to be treatable by topical administration. This application route has the advantage of strongly reducing systemic side effects.

Chemical optimization of compounds has been done either to improve activity, or to identify prodrugs that overcome suboptimal physicochemical properties of the active compound to enhance its availability. GCs with a predictable and rapid metabolism into inactive metabolites after exerting of pharmacologic effects at the site of disease are classified as soft drugs (Bodor and Buchwald, 2006). GCs that follow the prodrug and the soft drug principle have been designed. They are activated locally by enzymes in lung (e.g. ciclesonide, butixocort 21-propionate) or in skin (methylprednisolone aceponate) and show a low systemic exposure. These GCs locally inhibit pro-inflammatory cytokines and chemokines at the site of administration potently, whereas they elicit only limited systemic effects (O’Connel, 2003; Welker et al, 1996, Günther et al., 1998).

Although topical GCs are successfully used to treat several inflammatory respiratory and cutaneous diseases, their major limitation remains the local side effects they can cause. Furthermore, severe disease exacerbations cannot be treated efficiently with compounds that work locally only. In such situations, systemic treatment is mandatory, for example in bullous skin diseases and severe asthma. In dermatologic indication especially the main draw back of topical GCs is the development of skin atrophy after long-term use (Mills and Marks, 1993, Hengge et al., 2006).

Therefore, there is a great medical need for GC-like compounds that possess both an antiinflammatory / immunomodulatory activity similar to the marketed GCs and a reduced risk of undesired effects. 
In the past, different approaches to develop novel GCs or GC-substituting compounds with an improved effect / side effect ratio have been pursued. Besides optimization towards local administration several other strategies have been developed. First, optimization of formulation for systemic treatment leading to a more targeted release of the drug has been followed by some groups, e.g. by using liposomes encapsulating steroids for the treatment of rheumatoid arthritis (I). Second, introducing nitric oxide (NO) into the steroid scaffold was established to enhance anti-inflammatory activity without increasing the dose or potency of the steroid (II). However, one of the broadest and most promising approaches of the last 10 years is based on optimized GR-ligands which should address the molecular mechanisms of GR in a very specific way (III).

(I) The search for novel formulations was not only restricted to locally administered compounds, but also to GCs that are used for systemic treatments. One example is the encapsulation of prednisolone or dexamethasone in liposomes, e.g. PEG liposomes. In animal studies, pharmacodynamic and pharmacokinetic experiments demonstrated a prolonged and more targeted availability of the drug in comparison to the drug given without liposoms (Metselaar et al., 2004, Chono et al., 2005, Teshima et al., 2006). The high affinity of PEG liposomes for macrophages in inflamed tissues makes them attractive GC encapsulation agents. The macrophages do not serve as target cells only, but also play a crucial role in the release of GCs from liposomes and the generation of relatively high and prolonged concentration of active drug in the synovium. Especially in indications such as rheumatoid arthritis and atherosclerosis this administration form might lead to increased activity of the drug.

(II) A second approach to improve the ratio of desired to undesired effects was to combine chemically a known steroidal GR-ligand with NO, leading to e.g. nitroxy derivatives of prednisolone. The company, NicOx S.A, tested NCX-1015 (NO prednisolone) (Fig. 1) and NCX-1022 (NO hydrocortisone) (Fig. 1) in animal experiments regarding their anti-inflammatory activity (Hyun et al., 2004, Doggrell 2005). With NCX-1022 a phase II study including 40 patients with seborrheic dermatitis has been performed with promising results regarding efficacy and tolerability of the drug in topical application (NicOx S.A:, Media Release,: 29 April 2004. Available from: URL:http://www.nicox.com. Media release). With NCX-1015 a phase I study for indication Inflammatory Bowel Disease has been conducted also showing a good local tolerability and no systemic absorption (NicOx S.A., Press release, 14 February 2002, Available from. URL:http://www.nicox.com).

(III) Major efforts have been made and promising pre-clinical results have been achieved in the search for GR-ligands that trigger molecular mechanisms of the GR very selectively, with the goal of reducing the risk for side effects while maintaining the therapeutic efficacy of known GCs. To summarize the progress made with this approach we will give a very rough and brief overview on mechanisms of the GR and the working hypothesis used by a number of pharmaceutical companies to search for improved GR-ligands. 


\section{Glucocorticoid receptor and its molecular actions}

The receptor of GCs, the GR, is expressed ubiquitously. In its inactive form the receptor is located in the cytoplasm of cells, associated with molecular chaperones and immunophilins. After binding of the ligand to the GR, it dissociates from this complex and is transported into the nucleus to modulate the expression of specific genes. However, not all chaperones and co-chaperones dissociate; some of them are transported with the receptor into the nucleus (Morimoto, 2002). Although it has been shown that they modulate the action of the receptor, their biological significance is still unclear.

Similar to other nuclear receptors, the GR consists structurally of a C-terminal ligand binding domain (LBD), a DNA binding domain with a dimerization interface in the center of the molecule and two transcription activation domains, AF-1 and AF-2 (Wärnmark et al., 2003). In the ligand-activated state, the receptor modulates gene expression either positively (transactivation) or negatively (transrepression).

\section{Transactivation}

Positive regulation of gene expression by the GR has been shown to be mainly mediated by direct binding of receptor homodimers to specific sequences (glucocorticoid responsive elements (GREs)) in promoter or enhancer regions of GC target genes. Three different types of GREs, simple, composite, or tethering are known (Lefstin and Yamamoto, 1998), suggesting differences in the molecular mechanisms required for the respective types of GREs. Activation of gene transcription by the GR via simple and composite GREs is dependent on binding of the activated GR homodimer to DNA directly. At tethering GREs, the GR binds to other DNA-bound transcription factors such as STAT5 to increase transcription activity. The introduction of a point mutation in the dimerization domain of the GR was used to demonstrate in vitro that dimerization of the GR is a prerequisite for transactivation function (Heck et al., 1994). In mice carrying a dimerization-deficient GR the induction of several liver specific genes was strongly reduced (Reichardt et al., 1998). Transactivation of many but not all GC-regulated genes is dependent on dimerization of the GR. A screen to determine different sets of primary GR targets has shown that a large number is still transactivated even in the presence of the dimerization mutant. This indicates that other mechanisms of activation occur, possibly through the AF-1 and AF-2 domains of the receptor (Rogatsky et al., 2003).

\section{Transrepression}

Negative regulation by the GR (transrepression) occurs via different mechanisms. Well described is a regulation via negative GREs that differ in structure and function from positive GREs (Dostert and Heinzel, 2004). Such elements can be found at different positions in promoter regions. They interfere either with binding sites of other transcription factors, as shown in the promoter of the proopiomelanocortin (POMC) gene (Philips et al., 1997), or with the binding site of the basal transcription initiation complex, as described for the osteocalcin promoter (Meyer et al., 1997). 
Interestingly, only a few genes are known to be regulated via these negative GREs; therefore, the contribution of this kind of negative regulation to the overall anti-inflammatory activities or to the induction of undesired effects is not well understood (Cato et al., 2004; Doster and Heinzel, 2004).

The major mechanism of negative regulation by the GR is the ability of the receptor to inhibit the activity of other transcription factors by being tethered to these factors. This mechanism is fully functional with dimerization-defective GR (Heck at al., 1994, Reichardt et al., 1998; Tuckermann et al., 1999) and is therefore thought to occur through GR monomers. The transcription factors to which the GR is tethered include activator protein $1(\mathrm{AP}-1)$, nuclear factor- $\kappa \mathrm{B}(\mathrm{NF}-\mathrm{\kappa B})$ and interferon regulatory factor 3 (IRF3) (Reily et al., 2006; Ogawa et al., 2005). In addition, tethering of GR to NF$\kappa \mathrm{B}$ inhibits phosphorylation of serine 2 on one of the two sites on the carboxy-terminal domain of RNA polymerase II which is required for transcriptional initiation (Nissen and Yamamoto, 2000). Another report demonstrated that different domains of the GR seem to be responsible for either NF- $\mathrm{KB}$ or AP-1 interactions. $A_{G_{(R 488)}}$ mutant unable to repress $\mathrm{NF}-\kappa \mathrm{B}$ activity retained the ability to repress AP-1 activity while transactivation activities were unaffected (Bladh et al., 2004).

As these transcription factors regulate the expression of pro-inflammatory genes, their negative regulation by the GR has become a paradigm for the anti-inflammatory and immune suppressive action of glucocorticoids.

Other mechanisms used to explain the transrepressive function of the GR is the binding of the GR to Jun N-terminal kinase (JNK) leading to suppression of JNK activity and subsequently to inhibition of AP-1 (Caelles et al., 1997, Bruna et al., 2003). The GR is also known to interfere with the extracellular signal-regulated protein kinase (ERK-1 and ERK-2) and p38 MAP kinase pathways via increased expression of the dual-specificity MAP kinase phosphatase (Kassel et al. 2001, Lasa et al., 2002, Clark, 2003).

\section{Cofactors}

The GR as a ligand-activated transcription factor, however, does not function alone. To ensure highly coordinated regulation of gene transcription it requires coregulators to modify and remodel chromatin structures. Cofactors can be divided into coactivators and corepressors depending on their function (Rogatsky and Ivashkiv, 2006, Feige and Auwerx, 2007). They do not bind directly to DNA but they are recruited through protein:protein interactions with $\mathrm{AF}$ domains of the GR to regulatory sequences and can exert enzymatic activities, e.g. histone acetylases (HATs) or histone deacetylases (HDCAs). Among the best-described examples of co factors are CBP/p300 HATs, which function as coactivators for many transcription factors beside the GR. A second family of coactivators consists of p160 proteins, including SRC1/NCoA1, TIF2/GRIP1/NCoA3, pCIP/RAC3/ACTR/AIB1/NCoA3 (Xu and O'Malley, 2002). Interestingly, it was shown, that TIF2/GRIP1 is also able to function as a corepressor of the GR at the AP-1 and NF- $\mathrm{kB}$ 'tethering sites' (Rogatsky et al., 2001,). Other 
corepressors, such as NCoR and SMRT have been described as being recruited to nuclear receptors, too. Their role in the negative regulation of pro-inflammatory genes, however, is still not well recognized. Further studies to investigate GR-dependent cofactor recruitment using dissociated GRligands, as well as full agonists and/or antagonists, might help further to in crease our understanding of the fine tuning of gene expression regulated by the GR.

Much research effort was invested in the study of the molecular mechanisms of anti-inflammatory / immunomodulatory activity of GCs. However, these are still not fully understood. Behind the transrepression activity, several mechanisms are hidden. For example, the role of cofactors and histone deacetylases for example is still under discussion although much research has been done in the past (Ito et al., 2000; Ito et al., 2001; Vanden Berghe et al., 2002). Furthermore, there are also transactivation events induced by GCs that are therapeutically beneficial, as has been shown for example for MKP-1 (Kassel et al., 2001, Clark, 2003), lipocortin-1 (Calandra et al., 1995) or very recently for glucocorticoid-induced leucin zipper (GILZ) (Hamdi, et al., 2007). Nevertheless, repression of many pro-inflammatory molecules seems to be a major part of the anti-inflammatory effects of GCs.

\section{Selective modulation of GR action as a concept for separation of anti-inflammatory effects from side effects}

Although the molecular mechanisms of the GR are more diverse than described 10 years ago, the differentiation of positive and negative regulation of gene expression by the GR has provided a working model to search for novel synthetic GR-ligands that have a better therapeutic index than classical GCs. This concept is based on studies with a mutant GR, where the exchange of a single amino acid residue in the dimerization domain of the receptor molecule abrogated dimerization and transactivation activities of the GR without affecting the ability of the receptor to repress AP-1 regulated genes (Heck et al., 1994). Further studies with genetically modified mice carrying this dimerization deficient GR $\left(\mathrm{GR}^{\mathrm{dim} / \mathrm{dim}}\right)$ demonstrated a similar phenotype. The expression of a number of genes positively regulated by the GR was abolished while negatively regulated genes were not affected (Reichardt et al., 1998, Reichardt et al., 2001). Treatment of the GR ${ }^{\mathrm{dim} / \mathrm{dim}}$ mice with dexamethasone generated, in some models of anti-inflammatory action of GCs, a similar antiinflammatory response as in the wild type animals. For example, inflammatory activity, including the induced ear edema following TPA treatment and phorbol ester-induced local inflammation of the skin, could be repressed by glucocorticoids in the wild-type and GR ${ }^{\mathrm{dim} / \mathrm{dim}}$ mice (Reichardt et al., 2001). However, these mice have not been used in any long-term experiments to find out whether the known side effects of glucocorticoids are eliminated. In a recent study presented at Keystone Symposium Nuclear Receptors: Steroid Sisters in 2006, Tuckermann and colleagues showed that GR ${ }^{\mathrm{dim} / \mathrm{dim}}$ mice 
were not protected from developing GC-dependent osteoporosis after a two week systemic treatment with prednisolone (Tuckermann et al., 2006, Abstract Keystone Symposium Nuclear Receptors: Steroid Sisters). This result demonstrates, that some but not all side effects might be addressed by a reduced transactivation activity of the GR. However, results obtained with GR ${ }^{\mathrm{dim} / \mathrm{din}}$ mice might not be translated in a one to one relation to the profile of dissociated GR-ligands. It is important to note that while some transactivation function of the GR may be destroyed by the dimerization mutation, there are clearly some genes that are positively regulated by the GR that are not affected by this mutation (Adams et al., 2003).

The ability of the GR to function as coactivator in the positive regulation of genes controlled by, for example STAT5, is not affected by the dimerization and DNA binding properties of the receptor (Stocklin et al., 1996). Thus GC regulation of growth hormone expression and IGF-1 signaling is not affected by the dimerization mutation (Tronche et al., 2004). Similarly, there are genes that negatively regulate the immune system that are positively regulated by the GR. For example, thymosin $\beta 4$ sulfoxide (Young et al., 1999), glucocorticoid-induced leucine zipper (GILZ) (Berrebi et al., 2003), macrophage migration inhibitory factor (MIF) (Calandra et al., 1995), lipocortin-1 (Mizuno et al., 1997) and MKP-1 (Kassel et al., 2001) are some of the known genes that negatively regulate processes in the immune system but are transcriptionally upregulated by GCs. Thus the transactivation / transrepression model for the screening of anti-inflammatory glucocorticoids with reduced side effects, although attractive, has some limitations. In spite of this, several pharmaceutical companies were able to identify novel GR-ligands displaying a better therapeutic index in vivo by using the hypothesis of dissociation of transrepression from transactivation activities as a starting point in their compound searches.

\section{Identific ation of "dissociated" GR-ligands}

Several pharmaceutical companies and university groups have been working to identify specific GRligands with potent anti-inflammatory activity and reduced side effects, i.e. a therapeutically beneficial profile (Coghlan et al., 2003a, Högger, 2003; Cato et al., 2004, Schulz \& Eggert, 2004, Schäcke et al., 2005, Mohler et al., 2007). A screen for such ligands usually consists of receptor binding assays and cellular in vitro tests for GR-mediated transactivation and transrepression, followed by various animal models of inflammation and GC-mediated side effects. The compounds analyzed are derived from different sources such as from high throughput screening (where hundred of thousands of compounds are randomly screened) or from rational drug design, beginning with targeted modifications of known GR-ligands. 
The first dissociated GR-ligands were published by Roussel-Uclaf (now Sanofi-Aventis): RU 24782, RU 24858 and RU 40066 (all Fig. 2, Table 1). All of these compounds have a steroidal structure and show good dissociation in vitro. Unfortunately, this in vitro dissociation did not persist in the in vivo situation. While RU 24858 was as an anti-inflammatorily active as prednisolone in a rat asthma model, it induced side effects like those of the steroid itself: loss in body weight and induction of osteoporosis (Belvisi et al., 2001). This may be due to the steroidal structure of the compound. It is possible that this derivative is metabolized in vivo in such a way that yields a compound that behaves like a classical glucocorticoid.

The situation changed with the discovery of two structurally distinct new non-steroidal GR-ligands: AL-438 and ZK 216348 (both Fig. 2, Table 1). AL-438, a benzopyrano[3,4-f]quinoline derivative, synthesized during a collaboration between Abbott Laboratories and Ligand Pharmaceuticals, efficiently inhibits the production of IL-6 and E-selectin, through transrepression, while showing less activity in transactivation assays (Coghlan et al., 2003b). This dissociation was also confirmed in vivo. AL-438 inhibits inflammation in a rat asthma model while showing a decreased potential to induce blood glucose, a surrogate marker for diabetes induction, which is a side effect known to be connected with transactivation mechanisms. Furthermore, reports have been published describing that AL-438 may be less likely than prednisolone to induce osteoporosis. In a very recent publication it was demonstrated by in vitro experiments that AL-438 affects osteoblastic cells significantly less in comparison to dexamethasone and prednisolone (Owen et al., 2007). The structure activity relationship (SAR) of this scaffold has been described (Elmore et al., 2004). LGD-5552 (Table 1), another promising compound whose structure has not yet been published though it shares a similar scaffold, has proven its efficacy in several animal models (Braddock, 2007).

A different non-steroidal compound, ZK 216348 has been synthesized and characterized by (Bayer Schering Pharma AG) BSP (Schäcke et al., 2004). The structure is a pentanoic acid 4-methyl-1-oxo1H-2,3-benzoxazinamide bearing a hydroxyl and a trifluoromethyl group, and a methyl and aryl substituent in the $\omega$-position, resulting in two quaternary carbons. The compound shows a dissociated profile in vitro: it inhibits the production of IL-8 and induces fewer transactivation mediated effects, like the induction of tyrosine amino transferase (TAT), one of the key enzymes in gluconeogenesis. This dissociated profile persists in in vivo experiments. ZK 216348 reduces a croton oil-induced ear inflammation as effectively as prednisolone in rats and mice after subcutaneous or topical administration. Importantly, in contrast to the steroid, ZK 216348 displays an attenuated side effect profile, as determined by the induction of TAT and blood glucose and reduction in body and thymus weight. Furthermore, ZK 216348 shows less skin atrophy than the GC reference after long-term topical treatment. Similar to AL-438, ZK 216348 has been shown to not affect osteoblastic cells negatively in comparison to steroidal GR-ligands in vitro (Humphrey et al., 2005).

Compound A, 2-((4-Acetoxyphenyl)-2-chloro-N-methyl)ethylammonium chloride (Fig. 2, Table 1), is a stable analogue of the hydroxyl phenyl aziridine precursor found in the Namibian shrub Salsola 
tuberculatiformis Botschantzev and exhibits a dissociated profile with respect to the GR (De Bosscher et al., 2005). Compound A, described by Haegeman and coworkers, is the first example of such a dissociated compound isolated from natural sources. It binds to the GR with an affinity similar to dexamethasone. It is claimed that Compound A selectively triggers transrepression based on the results of in vitro experiments. Furthermore, the authors showed that it was possible to relate this in vitro dissociation to an in vivo context. According to the publication, Compound $\mathrm{A}$ is as active an antiinflammatory as dexamethasone in a zymosan-induced paw edema model in mice but induces no increase in the blood glucose level (De Bosscher et al., 2005).

BI 115 (Fig. 2, Table 1) is described in multiple patents, the earlier of which claim BI 115 to be a GR modulator. Pharmacological data were presented at the Edinburgh SCIPharm conference (May 14th17th 2006). BI 115 binds with high affinity to GR ( $\left.\mathrm{IC}_{50}: 2 \mathrm{nM}\right)$ and inhibits IL-6 with a potency of $6 \mathrm{nM}$ (90\% efficacy). The aromatase inhibition was reported to be $10 \mathrm{nM}$ (90\% efficacy). This compound was also tested in a collagen-induced arthritis model in mice. The result was described as a better profile in comparison to prednisolone regarding a number of parametersobtained in this model, especially metabolic parameters were less affected by BI 115 than by prednisolone. A structurally distinct BI compound (Table 1), an indole sulphonamide, was published in 2007 with a binding constant of $29 \mathrm{nM}$ to the human GR. (Marshall et al., 2007)

Glaxo Smith Kline (GSK) reported the benzylic position of their tetrahydronaphthalinemethylbenzoxazinones (Fig. 2, Table 1) as an agonist trigger in GR binding. Compounds of this class are claimed in two patents (WO2006/000398, WO2006/000401) each member of which has a binding below $100 \mathrm{nM}$ to GR. In a functional assay involving NF- $\mathrm{KB}$ inhibition the depicted cyclopentyl derivative had a pIC 50 of 8.7 (92\%) (Barker et al., 2006).

Other pharmaceutical companies are also working in the field of dissociated GR-ligands. For example, Pfizer is using a cell-based assay to find dissociating modulators of the GR (Rogatsky, 2003). Nonsteroidal selective GR-ligands, described by Merck Research Laboratories and University of California in San Francisco (Fig. 2, Table 1), have been shown to display a dissociated in vitro profile and to dose-dependently inhibit LPS-induced TNF- $\alpha$ production in mice (Shah and Scanlan, 2004, Thompson et al., 2005). However, no in vivo data have so far been reported on the potential of these compounds to induce GC-mediated side effects.

In general, it seems that the compounds identified on the basis of their conformity to the transrepression / transactivation hypothesis show anti-inflammatory activity with reduced side effects in some, but not in all, animal models. The focus in the search for novel GR-ligands at the moment is on systemic, preferentially orally bioavailable compounds. There are, however, programs aimed at the identification of compounds suitable for topical application, such as cutaneous application in dermatoses or inhaled therapy in asthma. Such compounds may require a different target profile. 
The required compound profiles for systemic and topical administrations may differ not only regarding their pharmacokinetic but also regarding their pharmacologic profiles. Thus, it appears that in the future emphasis should be placed on the identification of GR agonists for distinct antiinflammatory functions and administration routes. The molecular targets to be used in the screening process will be dictated by the properties required of the compound. Once in vivo efficacy and reduced side effect profile in at least one parameter has been demonstrated, the GR-ligand should be used for an in depth profiling regarding cofactor recruitment as well as for activity in different disease and side effect models.

\section{Summary and perspective}

In the last few years, the first promising results in the field of dissociated GR-ligands have been reported. A good correlation between an in vitro profile and a better therapeutic index in vivo has been shown for three compounds thus far: AL-438, ZK 216348, and BI 115. All compounds strongly inhibit the activity of pro-inflammatory transcription factors, but differ in their transactivation profiles. In vivo results show that they have the potential for an improved therapeutic index with regard to some but not all side effects. For example, ZK 216348 does not induce blood glucose after systemic treatment of rats (Schäcke et al., 2004), whereas AL-438 even antagonizes the blood glucose induction caused by predniso lone in vivo (Coghlan et al., 2003). However, not all aspects of in vivo selectivity of these compounds are completely understood.

In parallel to the work at different pharmaceutical companies, research in the field of molecular mechanisms of the GR, especially regarding anti-inflammatory activity, was carried out in many research laboratories. These results have demonstrated that the cellular role of the GR is substantially more complex than the one described 15 years ago. Anti-inflammatory activity of GCs is regulated to a major extent by the repression of pro-inflammatory proteins, but not exclusively. Even in discussing transrepression it is now clear that several distinct molecular processes are implied by this term.

Likewise, the mechanisms involved in the development of undesired effects are complex and subtle. For many of the metabolic effects transactivation seems to be the most prominent mechanism as it has been shown for genes encoding enzymes of gluconeogensis and protein catabolism (Schäcke et al., 2002). However, especially with regard to osteoporosis induction, the dissociation between transactivation and transrepression activity will not be a comprehensive indicator of how the compound will behave (Tuckermann et al., 2006). Similarly, mechanisms for the induction of skin atrophy are not very well understood. For these and some other side effects, it might be more helpful to establish very specific in vitro systems, where possible, to determine the characteristics of newly synthesized compounds with regard to specific therapeutic and side effects.

Further research is required to identify more molecular pathways that could ease the in vitro screening procedure by clearly identifying therapeutically useful GR agonists. 
Some of the useful parameters to be included in future screening assay to improve the identification of "dissociated" compounds are: first, a better understanding of the tissue-specific recruitment of coactivators and corepressors by the GR-ligand complex, and; second, determination of the changes in gene expression profiles caused about by the GR-ligand complex. In this context, the changes in protein expression pattern brought about by the GR-ligand complex should not be disregarded. Furthermore, detailed molecular analysis of GR-ligand complexes at the promoter level, by means of chromatin immunoprecipitation techniques to determine the recruitment of chromatin-modifying enzymes such as histone acetylases and deacetylases or protein methylases, would give valuable insight into the function of particular ligands when bound to the GR.

Beside all the restrictions regarding the transrepression / transactivation hypothesis mentioned above, there are examples of dissociated GR-ligands (AL-438, ZK 216348, BI 155) that display an improved effect / side effect ratio in animals. Whether these results will also hold true in humans remains to be shown in a clinical setting. We expect that dissociated GR-ligands will soon enter the development stage, and subsequently demonstrate their clinical superiority.

\section{Acknowledgement}

We would like to thank Prof. Dr. Andrew Cato (FZK, Karlsruhe) for the helpful discussions over many years in all phases of the project. 


\section{References:}

Adams, M., Meijer, O.C., Wang, J., Bhargava, A., Pearce, D., 2003. Homodimerization of the glucocorticoid receptor is not essential for response element binding: activation of the phenylethanolamine N-methyltransferase gene by dimerization-defective mutants. Mol. Endocrinol. $17,2583-2592$.

Barker, M., Clackers, M., Copley, R., Demaine, D.A., Humphreys, D., Inglis, G.G., Johnston, M.J., Jones, H.T., Haase, M.V., House, D., Loiseau, R., Nisbet, L., Pacquet, F., Skone, P.A., Shanahan, S.E., Tape, D., Vinader, V.M., Washington, M., Uings, I., Upton, R., McLay, I.M., Macdonald, S.J., 2006. Dissociated nonsteroidal glucocorticoid receptor modulators; discovery of the agonist trigger in a tetrahydronaphtalene-benzoxazine series. J. Med. Chem. 49, 4216-4231

Barton, B.E., Jackway, J.P., Smith, S.R., Siegel, M.I., 1991. Cytokine inhibition by a novel steroid, mometasone furoate. Immunopharmacol Immunotoxicol 13, 251-261.

Belvisi, M.G., Wicks, S., Battram, C.H., Bottoms, S.E.W., Redford, J.E., Woodmann, P., Brown, T.J., Webber, S.E., Foster, M.L., 2001. Therapeutic benefit of a dissociated glucocorticoid and the relevance of in vitro separation of transrepression from transactivation activity. J. Immunol. 166, 1975-1982.

Berreb,i D., Bruscoli, S., Cohen, N., Foussat, A., Migliorati, G., Bouchet-Delbos, L., Maillot, M.C., Portier, A., Couderc, J., Galanaud, P., Peuchmaur, M., Riccardi, C., Emilie, D., 2003. Synthesis of glucocorticoid-induced leucine zipper (GILZ) by macrophages: an anti-inflammatory and immuno suppressive mechanism shared by glucocorticoids and IL-10. Blood. 101, 729-738.

Bodor, N., Buchwald, P., 2006. Corticosteroid Design for the Treatment of Asthma: Structural Insights and the Therapeutic Potential of Soft Corticosteroids. Curr. Pharm. Design 12, 3241-3260.

Braddock, M., 2007. Advances in Anti-inflammatory Therapeutics: 20-21 November 2006, London, UK. Expert Opin. Investig. Drugs 16, 257-261.

Calandra, T., Bernhagen, J., Metz, C.N., Spiegel, L.A., Bacher, M., Donnelly, T., Cerami, A., Bucala, R., 1995. MIF as a glucocorticoid-induced modulator of cytokine production. Nature. 377, 68-71.

Cato, A.C., Schäcke, H., Sterry, W., Asadullah, K., 2004. The glucocorticoid receptor as target for classic and novel anti-inflammatory therapy. Curr. Drug Target Inflamm. Allergy 3, 347-353.

Chono, S:, Tauchi, Y., Deguchi, Y, Morimoto, K., 2005. Efficient drug deliverly to atherosclerotic lesions and the antiatherosclerotic effect by dexamethasone incorporated into liposomes in atherogenic mice. J. Drug Target 13, 267-276.

Clark, A.R., 2003. MAP kinase phosphatase 1: a novel mediator of biological effects of glucocorticoids? J Endocrinol 178, 5-12.

Coghlan, M.J., Elmore, S.W., Kym, P.R., Kort, M.E., 2003a. The pursuit of differentiated ligands for the glucocorticoid receptor. Curr. Topics Med. Chem. 3, 1617-1635.

Coghlan, M.J., Jacobson, P.B., Lane, B., Nakane, M., Lin, C.W., Elmore, S.W., Kym, P.R., Luly, J.R., Carter, G.W., Turner, R., Tyree, C.M., Hu, J., Elgort, M., Rosen, J., Miner, J.N., 2003b. A novel antiinflammatory maintains glucocorticoid efficacy with reduced side effects. Mol. Endocrinol. 17, 860869 .

De Bosscher, K., Vanden Berghe, W., Beck, I.M.E., Van Molle, W., Hennuyer, N., Hapgood, J., Libert, C., Staels, B., Louw, A., Haegeman, G., 2005. A fully dissociated compound of plant origin for inflammatory gene repression. Proc. Nat. Acad. Sci. USA 102, 15827-15832. 
Doggrell, S., 2003. Is AL-438 likely to have fewer side effects than the glucocorticoids? Expert Opin. Invest. Drugs 12, 1227-1229.

Doggrell, S., 2005. The nitrosterols - a step forward from the steroid anti-inflammatory drugs? Expert Opin. Investig. Drugs 14, 823-828

Dostert, A., Heinzel, T., 2004. Negative glucocorticoid receptor response elements and their role in glucocorticoid action. Curr. Pharm. Des. 10, 2807-2816.

Elmore, S.W., Pratt, J.K., Coghlan, M.J., Mao, Y., Green, B.E., Anderson, D.D., Stashko, M.A., Li, C.W., Falls, D., Nakane, M., Miller, L., Tyree, C.M., Miner, J.N., Lane, B., 2004. Differentiation of in vitro transcriptional repression and activation profiles of selective glucocorticoid receptor modulators. Bioorgan. Med. Chem. Lett. 14, 1721-1727.

Feige, J.N., Auwerx, J., 2007. Transcriptional coregulators in the control of energy homeostasis. Trends in Cell Biol. [Epub ahead of print]

Günther, C., Kecskes, A., Staks, T., Täuber, U., 1998. Percutaneous absorption of methylprednisolone aceponate following topical application of Advantan ${ }^{\circledR}$ lotion on intact, inflamed and stripped skin of male volunteers. Skin Pharmacol. Appl. Skin Physiol. 11, 35-42.

Hench, P.S., Kendall, E.C., Slocumb, C.H., Polley, H.F., 1949. Effect of hormone of adrenal cortex (17-hydro xy-11-dehydrocorticosterone: compound E) and of pituitary adrenocortico tropic hormone on rheumatoid arthritis: preliminary report. Proc. Staff Meet., Mayo Clin. 24, 181-197.

Hench, P.S., Kendall, E.C., Slocumb, C.H., Polley, H.F., 1950. Effects of cortisone acetate and pituitary ACTH on rheumatoid arthritis, rheumatic fever and certain other conditions. Arch. Med. Interna. 85, 545-666

Heck, S., Kullmann, M., Gast, A., Ponta, H., Rahmsdorf, H.J., Herrlich, P., Cato, A.C.B., 1994 A distinct modulating domain in glucocorticoid receptor monomers in the repression of activity of the transcription of AP-1. EMBO J. 13, 4087-4095.

Hengge, U.R., Ruzicka, T., Schwartz, R.A., Cork, M.J., 2006. Adverse effects of topical glucocorticosteroids. J. Am. Acad. Dermatol. 54, 1-15.

Högge,r P., 2003. Current concepts for optimizing the therapeutic index of glucocorticoid receptor ligands for oral inhalative use: basic considerations and clinical reality. Curr. Med. Chem. 2, 395-408.

Humphrey, E.L., Williams, J.H.H., Davie, M.W.J., Marshall, M.J., 2006. Effects of dissociated glucocorticoids on OPG and RANKL in osteoblastic cells. Bone 38, 652-661

Hyun, E., Bolla, M., Steinhoff, M., Wallace, J.L., del Soldato, P., Vergnolle, N., 2004. Antiinflammatory effects of nitric oxide-releasing hydrocortisone NCX 1022, in a murine model of contact dermatis. Br. J. Pharmacol. 143, 618-625

Ito, K., Barnes, P.J., Adcock, I.M., 2000. Glucocorticoid receptor recruitment of histone deacetylase 2 inhibits interleukin-1 $\beta$-induced histone H4 acetylation on lysines 8 and 12. Mol. Cell. Biol. 20,68916903.

Ito, K., Jazrawi, E., Cosio, B., Barnes, P.J., Adcock, I.M., 2001. p65-activated histone acetyltransferase activity is repressed by glucocorticoids: mifepristone fails to recruit HDAC2 to the p65-HAT complex. J. Biol. Chem. 276, 30208-30215. 
Kasse1, O., Sancono, A., Krätzschmar, J., Kreft, B., Stassen, M., Cato, A.C., 2001. Glucocorticoids inhibit MAP kinase via increased expression and decreased degradation of MKP-1. EMBO J. 20, 7108-7116.

Lasa, M., Abraham, S.M., Boucheron, C., Saklatvala, J., Clark, A.R., 2002. Dexamethasone causes sustained expression of mitogen-activated protein kinase (MAPK) phosphatase 1 and phosphatasemediated inhibition of MAPK p38. Mol. Cell. Biol. 22, 7802-7811.

Marshall, D.R., Rodrigues, G., Thomson, D.S., Nelson, R., Carolina, A., 2007. Alpha-methyltryptamin sulphonamide derivatives as novel gluco corticoid receptor ligands. Bioorg. Med. Chem. Lett. 17, $315-$ 319.

Mason, H.L., Myers, C.S., Kendall, E.C., 1936. The chemistry of crystalline substances isolated from the suprarenal gland. J. Biol. Chem. 114, 613-631.

Mason, H.L., Myers, C.S., Kendall, E.C., 1936a. Chemical studies of the suprarenal cortex II. The definition of a substance which possesses the qualitative action of cortin; its conversion into a diketone closely related to androstenedione. J. Biol. Chem. 116, 267-76.

Metselaar, J.M., van den Berg, W.B., Holthuysen, A.E, Wauben, M.H., Storm, G., van Lent, P.L., 2004. Liposomal targeting of glucocorticoids to synovial linig cells strongly increases therapeutic benefit in collagen type II induced arthritis. Ann. Rheum. Dis. 63, 348-353.

Meyer, T., Gustafsson, J.A., Carlstedt-Duke, J., 1997. Glucocorticoid-dependent transcriptional repression of the osteocalcin gene by competitive binding at the TATA box. DNA Cell. Biol. 16, 919927.

Mills, C. M., Marks, R., 1993. Side effects of topical glucocorticoids. Curr. Probl. Dermatol. 21, 122131.

Miner, J.N., Hong, M.H., Negro-Vilar, A., 2005. New and improved glucocorticoid receptor ligands. Expert Opin. Investig. Drugs 14, 1527-1545.

Mizuno, H., Uemura , K., Moriyama, A., Wada, Y., Asai, K., Kimura, S., Kato, T., 1997. Glucocorticoid induced the expression of mRNA and the secretion of lipocortin 1 in rat astrocytoma cells. Brain Res. 764, 256-264

Mohler, M.L., He, Y., Wu, Z., Hong, S.S., Miller, D.D., 2007. Dissociated non-steroidal glucocorticids: tuning out untoward effects. Expert Opin. Ther. Patents 17, 37-58.

Morimoto, R.I., 2002. Dynamic remodeling of transcription complexes by molecular chaperones. Cell $110,281-284$.

O'Connell, E.J., 2003. Review of the unique properties of budesonide. Clin Ther 25 (Suppl. C), C4260 .

Ogawa, S., Lozach, J., Benner, C., Pascual, G., Tangirala, R.K., Westin, S., Hoffmann, A., Subramaniam, S., David, M., Rosenfeld, M.G., Glass, C.K., 2005. Molecular determinants of crosstalk between nuclear receptors and toll-like receptors. Cell 122, 707-721.

Owen, H.C., Miner, J.N., Ahmed, S.F., Farguharson, C., 2007.The growth plate sparing effects of the selective glucocorticoid receptor modu lator AL-438. Mol. Cell. Endocrinol. 264, 164-170

Philips, A., Maira, M., Mullick, A., Chamberland, M., Lesage, S., Hugo, P., Drouin, J., 1997. Antagonism between Nurr77 and glucocorticoid receptor for control of transcription. Mol. Cell. Biol. 17, 5952-5959. 
Reichardt, H.M., Kaestner, K.H., Tuckermann, J., Kretz, O., Wessely, O., Bock, R., Gass, P., Schmid, W., Herrlich, P., Angel, P., Schütz, G., 1998 DNA binding of the glucocorticoid receptor is not essential for survival. Cell 93, 531-541.

Reichardt, H.M., Tuckermann, J.P., Göttlicher, M., Vujic, M., Weih, F., Angel, P., Herrlich, P., Schütz, G., 2001. Repression of inflammatory responses in the absence of DNA binding by the glucocorticoid receptor. EMBO J. 20, 7168-7173.

Reily, M.M., Pantoja, C., Hu, X., Chinenov, Y., Rogatsky, I., 2006. The GRIP1:IRF3 interaction as a target for glucocorticoid receptor-mediated immunosuppression. EMBO J. 25, 108-117.

Rogatsky, I., Zarember, K.A., Yamamoto, K.R., 2001. Factor recruitment and TIF2/GRIP1 corepressor activity at a collagenase-3 response element that mediates regulation by phorbol esters and hormones. EMBO J. 20, 6071-6083

Rogatsky, I., 2003. Drug discovery for inflammatory diseases. Expert Opin. Biol. Ther. 3, 1001 -1004.

Rogatsky, I., Wang, J.C., Derynck, M.K., Nonaka, D.F., Khodabakhsh, D.B., Haqq, C.M., Darimont, B.D., Garabedian, M.J., Yamamoto, K.R., 2003. Target-specific utilization of transcriptional regulatory surfaces by the glucocorticoid receptor. Proc. Nat. Acad. Sci. 100, 13845-13850.

Rogatsky, I., Ivashkiv, L.B., 2006. Glucocorticoid modulation of cytokine signalling. Tissue Antigens $68,1-12$

Schäcke, H., Döcke, W.D., Asadullah, K., 2002. Mechanisms involved in the side effects of glucocorticoids. Pharmacol. \& Therapeutics 96, $23-43$.

Schäcke, H., Schottelius, A., Döcke, W.D., Strehlke, P., Jaroch, S., Schmees, N., Rehwinkel, H., Hennekes, H., Asadullah, K., 2004. Dissociation of transactivation from transrepression by a selective glucocorticoid receptor agonist leads to separation of therapeutic effects from side effects Proc. Nat. Acad. Sci. USA 101, 227-232.

Schäcke, H., Rehwinkel, H., Asadullah, K., 2005. Dissociated glucocorticoid receptor ligands: compounds with an improved therapeutic index. Curr. Opin. Investig. Drugs 6, 503-507

Schulz, M., Eggert, M., 2004. Novel ligands: fine tuning the transcriptional activity of the glucocorticoid receptor. Curr. Pharm. Design 10, 2827-2826.

Shah, N., Scanlan, T.S., 2004. Design and evaluation of novel nonsteroidal dissociating glucocorticoid receptor ligands. Bioorganic \& Med. Chem. Lett. 14, 5199-5203.

Stocklin, E., Wissler, M., Gouilleux, F., Groner, B., 1996. Functional interactions between Stat5 and the glucocorticoid receptor. Nature 383, 726-728.

Teshima, M., Fumoto, S., Nishida, K., Nakamura, J., Ohyama, K., Nakamura, T., Ichikawa, M., Saski, H., 2006. Prolonged blood concentration of prednisolone after intravenous injection of liposomal palimtoyl prednisolone. J. Control. Release 112, 320-328.

Thompson, C.F., Quraishi, N., Ali, A., Tata, J.R., Hammond, M.L., Balkovec, J.M., Einstein, M., Ge, L., Harris, G., Kelly, T.M., Mazur, P., Pandit, S., Santoro, J., Sitlani, A., Wang, C., Williamson, J., Miller, D.K., Yamin, T.D., Thompson, C.M., O’Neill, E.A., Zaller, D., Forrest, M.J., Carballo-Jane, E. Luell, S., 2005. Novel heterocyclic glucocorticoids: in vitro profile and in vivo efficacy. Bioorg. Med. Chem. Lett. 15, 2163-2167. 
Tronche, F., Opherk, C., Moriggl, R., Kellendonk, C., Reimann, A., Schwake, L., Reichardt, H.M., Stangl, K., Gau, D., Hoeflich, A., Beug, H., Schmid, W., Schutz, G., 2004. Glucocorticoid receptor function in hepatocytes is essential to promote postnatal body growth. Genes Dev. 18, 492-497.

Tuckermann, J.P., Reichardt, H.M., Arribas, R., Richter, K.H., Schütz, G., Angel, P., 1999. The DNA binding-independent function of the glucocorticoid receptor mediates repression of AP-1-dependent genes in skin. J. Cell. Biol. 147, 1365-1370.

Vanden Berghe, W., De Bosscher, K., Vermeulen, L., De Wilde, G., Haegeman, G., 2002. In Proceedings of the ESRF workshop: Recent advances in glucocorticoid receptor action. Cato, Schäcke, Asadullah (Eds.), Springer: Berlin, Heidelberg, pp.233-278.

Wärnmark, A., Treuter, E., Wright, A.P.M., Gustafson, J.A., 2003. Activation functions 1 and 2 of nulear receptors: molecular strategies for transcriptional activation. Mol. Endocrinol. 17, 1901-1909.

Welker, P., Lippert, U., Nurnberg, W., Kruger-Krasagakes, S., Moller, A., Czarnetzki, B.M., 1996. Glucocorticoid-induced modulation of cytokine secretion from normal and leukemic human myelomono cytic cells. Int. Arch. Allergy Immunol. 109, 110-115.

Xu, J., O’Malley, B.W., 2002. Molecular and cellular biology of steroid receptor coactivator (SRC) family in steroid receptor function. Rev. Endocr. Metab. Disord. 3, 185-192

Young, J.D., Lawrence, A.J., MacLean, A.G., Leung, B.P., McInnes, I.B., Canas, B., Pappin, D.J., Stevenson, R.D., 1999. Thymosin beta 4 sulfoxide is an anti-inflammatory agent generated by monocytes in the presence of glucocorticoids. Nat. Med. 5, 1424-1427. 


\begin{tabular}{|c|c|c|c|}
\hline Compound & Reported effects & Status & Reference \\
\hline RU 24858, Sanofi-Aventis & $\begin{array}{l}\text { In vitro: dissociation between } \\
\text { transrepression and transactivation } \\
\text { activities; } \\
\text { In vivo: shows anti-inflammatory activity, } \\
\text { but has no impro ved effect/ side effect } \\
\text { profile }\end{array}$ & preclinical & $\begin{array}{l}\text { Belvisi et al., } \\
2001\end{array}$ \\
\hline AL-438, Abbott-Ligand & $\begin{array}{l}\text { In vitro: marked preference for } \\
\text { transrepression; } \\
\text { In vivo: shows anti-inflammatory activity } \\
\text { with an improved effect/ side effect profile }\end{array}$ & preclinical & $\begin{array}{l}\text { Coghlan et al., } \\
2003\end{array}$ \\
\hline LGD-5552, Ligand & $\begin{array}{l}\text { In vivo: shows anti-inflammatory activity } \\
\text { with an improved effect/ side effect profile }\end{array}$ & preclinical & Braddock, 2007 \\
\hline $\begin{array}{l}\text { ZK 216348, Bayer Schering } \\
\text { Pharma }\end{array}$ & $\begin{array}{l}\text { In vitro: clear preference for } \\
\text { transrepression; } \\
\text { In vivo: shows anti-inflammatory activity } \\
\text { with an improved effect/ side effect profile }\end{array}$ & preclinical & $\begin{array}{l}\text { Schäcke et al., } \\
2004\end{array}$ \\
\hline $\begin{array}{l}\text { Compound A, University of } \\
\text { Ghent }\end{array}$ & $\begin{array}{l}\text { In vitro: dissociation between } \\
\text { transrepression and transactivation } \\
\text { activities; } \\
\text { In vivo: shows anti-inflammatory activity } \\
\text { with an improved effect/ side effect profile }\end{array}$ & preclinical & $\begin{array}{l}\text { De Bosscher et } \\
\text { al., } 2005\end{array}$ \\
\hline BI 1 15, Boehringer Ingelheim & $\begin{array}{l}\text { In vitro: activity is shown } \\
\text { In vivo: shows anti-inflammatory activity } \\
\text { with an improved effect/ side effect profile }\end{array}$ & preclinical & $\begin{array}{l}\text { Conference } \\
\text { report: Edinburgh } \\
\text { SCIPharm, } 2006\end{array}$ \\
\hline $\begin{array}{l}\text { Compound 5g in reference } \\
\text { Marshall, Boehringer } \\
\text { Ingelheim }\end{array}$ & In vitro: binding data only reported & preclinical & $\begin{array}{l}\text { Marshall et al., } \\
2007\end{array}$ \\
\hline $\begin{array}{l}\text { Compound } 60 \text { in reference } \\
\text { Barker, GSK }\end{array}$ & $\begin{array}{l}\text { In vitro: dissociation between } \\
\text { transrepression and transactivation } \\
\text { activities; } \\
\text { In vivo: shows anti-inflammatory activity }\end{array}$ & preclinical & Barker et al., 2006 \\
\hline $\begin{array}{l}\text { Compound } 25 \text { in reference } \\
\text { Shah and Scanlan, UC-SF; } \\
\text { Compound } 15 \text { in reference } \\
\text { Thompson, Merck Research } \\
\text { Laboratories }\end{array}$ & $\begin{array}{l}\text { In vitro: dissociation between } \\
\text { transrepression and transactivation } \\
\text { activities; } \\
\text { In vivo: reduces TNF- } \alpha \text { production in mice }\end{array}$ & preclinical & $\begin{array}{l}\text { Shah and Scanlan, } \\
\text { 2004; Thompson } \\
\text { et al., } 2005\end{array}$ \\
\hline
\end{tabular}

Table 1 : Summary of dissociated GR-ligands. 


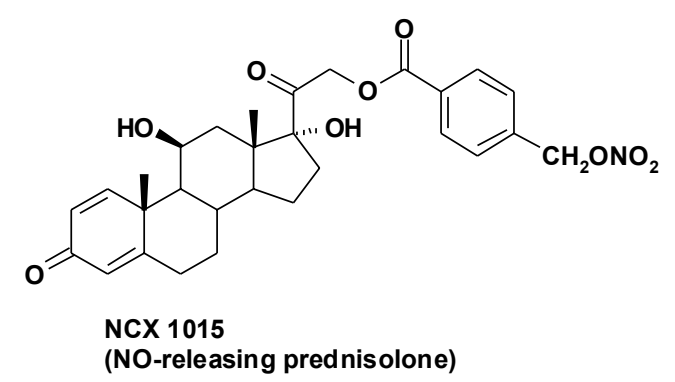

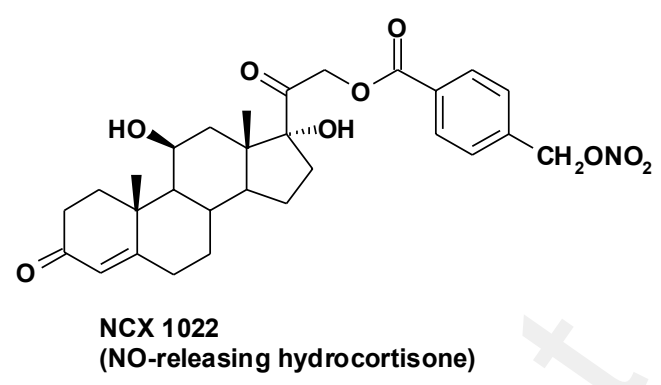

Figure 1: Structures of NO-releasing steroids. 
<smiles>C[C@H]1CC2C3CCC4=CC(=O)C=C[C@]4(C)C3[C@@H](O)C[C@]2(C)[C@H]1C(=O)CC#N</smiles>

RU 24858

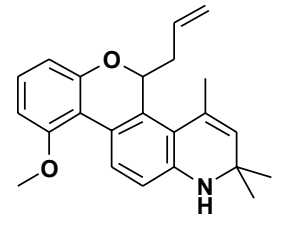

AL-438<smiles>Cc1noc(=O)c2ccc(NC(=O)C(C)(O)C(C)(C)c3cccc4c3OCC4)cc12</smiles>

ZK 216348<smiles></smiles>

Compound A

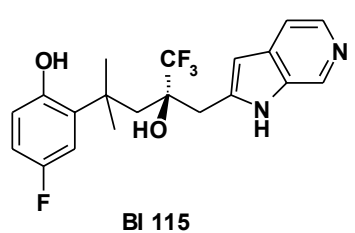

BI 115<smiles>Cc1cc(C)c(S(=O)(=O)NC(C)Cc2c[nH]c3ccccc23)c(C)c1</smiles>

BI

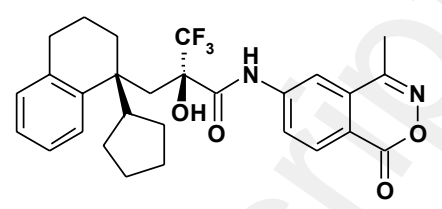

GSK

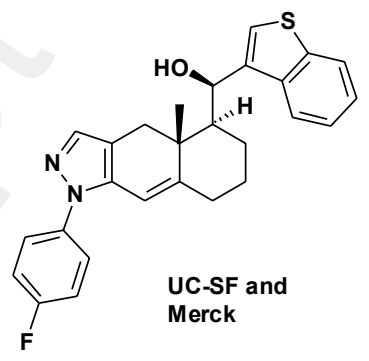

Figure 2: Structures of dissociated GR-ligands 